\title{
DESPLAZAMIENTO FORZADO, EXPERIENCIAS Y MEDIOS DE COMUNICACIÓN
}

Experiencia de intervención social realizada en el barrio Pízamos I.

Dirigida a un grupo de mujeres desplazadas por la violencia provenientes del Pacífico colombiano

Por:

\section{Eliana Noscué Mera ${ }^{1}$}

Grupo de Periodismo e información

Investigadora del proyecto

Universidad del Valle

\section{Ana Paola Angulo}

Comunicadora Social y Periodista2011

Co-Investigadora del Proyecto

Grupo de Periodismo e información

Universidad del Valle

\section{Resumen:}

Este artículo presenta el proceso metodológico de una experiencia de intervención social en comunicación en la que participaron seis mujeres desplazadas, afrocolombianas, provenientes del Pacífico colombiano. Se examinan la metodología aplicada y los desafíos que implica intentar construir un espacio de diálogo, conversación y narración en el que las participantes analizan las representaciones que los medios de comunicación hacen de los sujetos en situación de desplazamiento y las contrastan con su propia experiencia.

\section{Palabras claves:}

Mujer Afrocolombiana, Desplazado(a) por la violencia, Etnicidad, Identidad étnica, Prácticas culturales, Minoría, Territorio, Comunidad negra, Ciudadanía, Segregación, Los "no lugares".

${ }^{1}$ Licenciada en Literatura 2008, Comunicadora Social y Periodista 2011, Joven Investigadora Colciencias 2009 


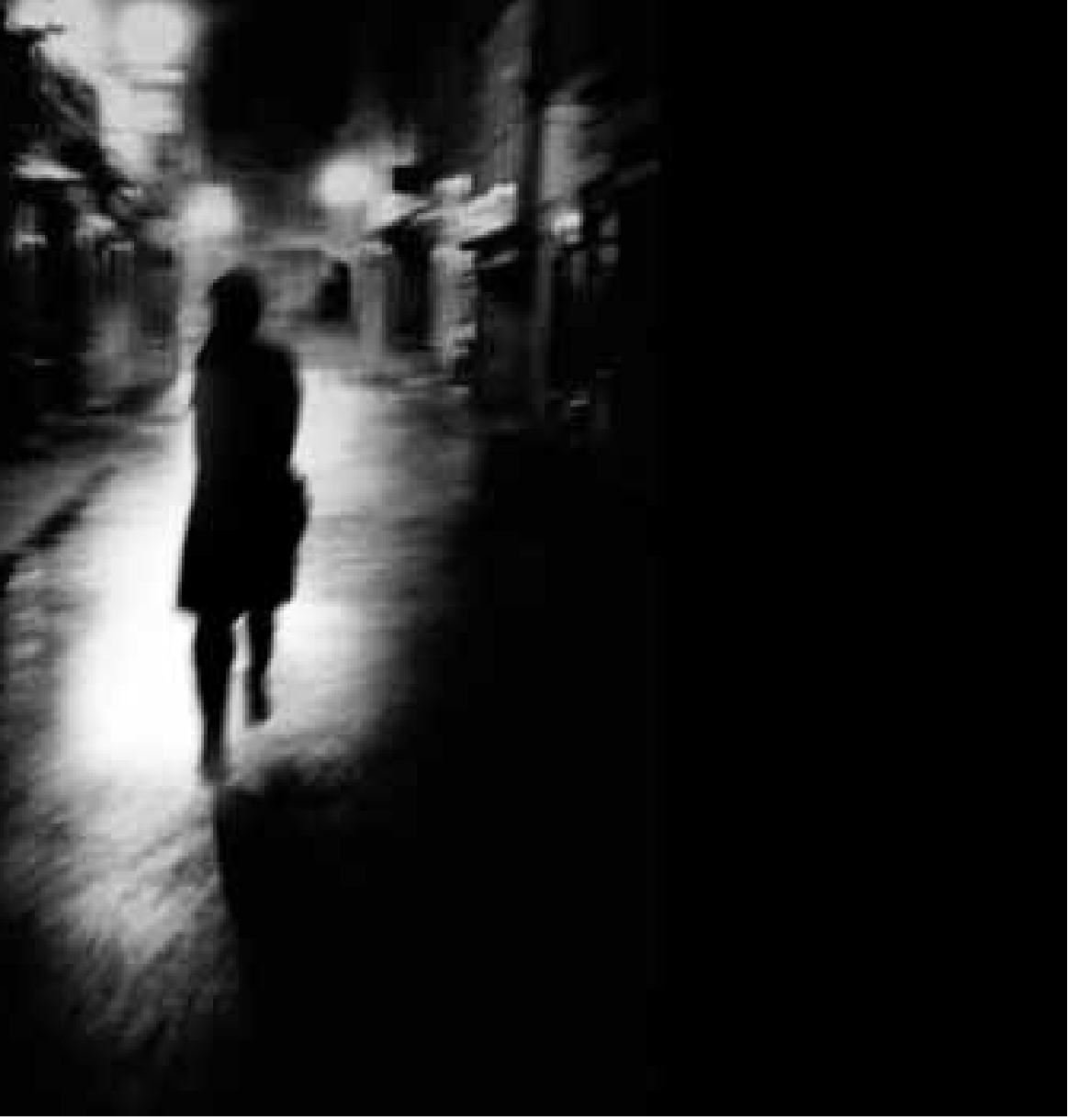

\section{Presentación}

Esta investigación se fundamenta en una experiencia de intervención social realizada con un grupo de mujeres desplazadas por la violencia, provenientes del Pacífico colombiano. La intervención se desarrolló entre Mayo 15 y Junio 26 de 2010, con una duración de seis semanas y una intensidad de tres horas semanales. El barrio Pízamos I, ubicado en el Distrito de Aguablanca de la ciudad de Cali, fue su lugar de realización. ${ }^{1}$

Planteamos que existe una diferencia sustancial entre el escenario mediático televisivo y la experiencia real de las personas en situación de desplazamiento forzado, provenientes del Pacífico colombiano. La hipótesis de esta disparidad nos llevó a enfocar la investigación en un trabajo de campo etnográfico y reflexivo.

Una de nuestras grandes preocupaciones como investigadoras sociales es que la manera como se representa a los desplazados por la violencia incide en la agenda política del país. Puede ocasionar que estén o no en los debates públicos y afecta a los que toman las decisiones políticas. Estas formas de representación pueden influir en las mentes de los ciudadanos, que podrían tener una visión solidaria, victimizarlos o rechazarlos. Entonces: “(...) los medios responden a la condición de impregnación, lo que los llevará a construir los universos del discurso del espacio público configurándolos en la forma de secciones: política, economía, deportes, cultura, ciencias, religión, etcétera" ${ }^{2}$. 
En todo el proceso, no solo vimos al grupo de mujeres que nos acompañaron como personas en condición de víctimas del desplazamiento forzado, sino como mujeres afrocolombianas que tienen una cultura importante y pertenecen a un territorio específico. Nuestra pretensión fue propiciar en ellas una actitud reflexiva sobre su condición de desplazadas por la violencia, examinando algunas noticias de televisión. Esperábamos comprender su condición, a través de la lectura y análisis que estas mujeres hacían de las noticias de televisión sobre desplazamiento. Estábamos interesadas en examinar el contraste entre el modo como los medios de comunicación informan y representan el desplazamiento forzado y la narración que ellas hacen de su propia experiencia de vida.

Decidimos enfocar nuestra investigación con las personas en situación de desplazamiento forzado provenientes del Pacífico colombiano, porque vemos necesario investigar y atender a los cambios, rupturas o transformaciones que estas poblaciones deben enfrentar por el flagelo del conflicto armado.

"El desplazamiento rompe el relato biográfico de las personas y las comunidades, el cual suele expresarse como: "antes y después de...", “yo era y ahora soy...”. La imagen que las personas construyen de sí mismas, sus atributos y señales distintivas, son alteradas profundamente al perderse sus prácticas cotidianas ligadas al trabajo, el territorio, las prácticas culturales y los roles sociales; también, al afectarse su estatus, lenguaje, formas de transacción, solidaridad y reciprocidad.

Asimismo, los daños en la identidad se asocian con las experiencias de discriminación, estigmatizaciónymaltrato, recibidasdurante eldesplazamiento por parte de los actores armados, y después del desplazamiento por parte de las comunidades receptoras, las autoridades y los funcionarios encargados de prestar atención. En algunos casos, también por la persistencia de amenazas y persecuciones que se extienden a los lugares de llegada". ${ }^{3}$

Nos cuestionamos cómo los medios de comunicación transmiten a la población colombiana los efectos, consecuencias, actores; víctimas y victimarios, de este problema de orden nacional. Nos preocupa no sólo que las personas provenientes del Pacífico colombiano que están llegando a la ciudad de Cali no posean las condiciones óptimas para vivir de forma digna, conservando sus raíces y conocimientos ancestrales, sino fundamentalmente cómo se transmite a la opinión pública su condición de desplazados por la violencia.

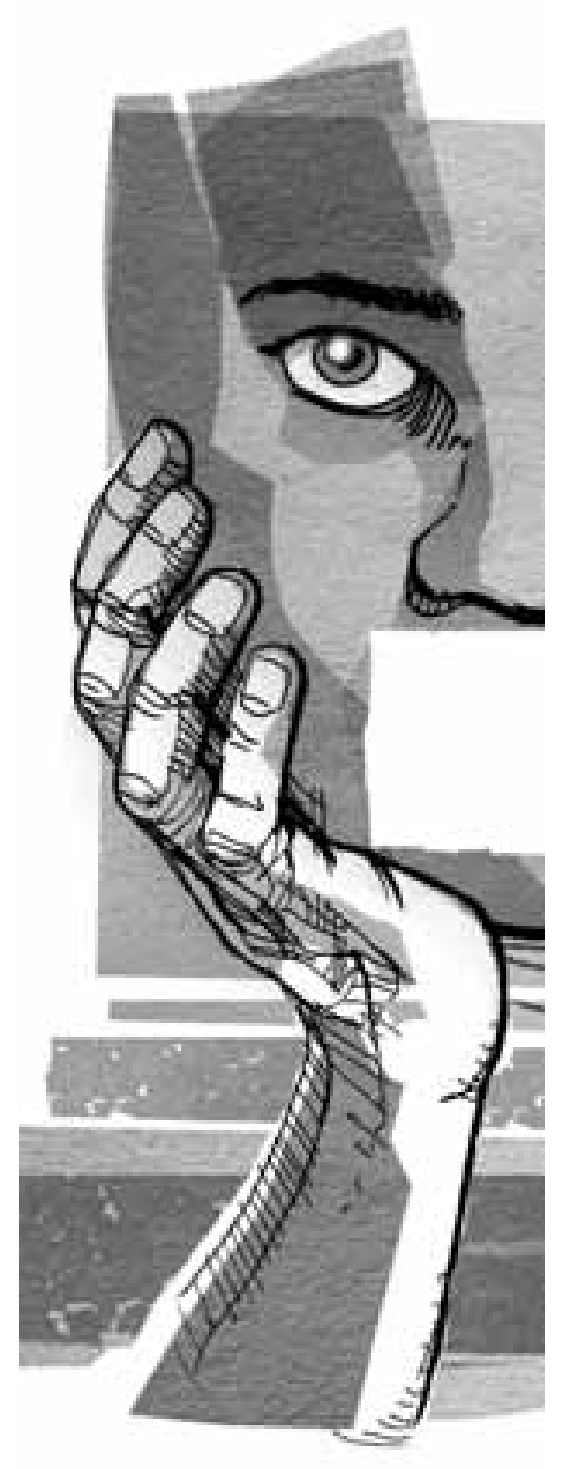

"El desplazamiento forzoso, sus causas y las tácticas de los grupos armados para expulsar población no son un fenómeno exclusivo del conflicto reciente. Durante la época de La Violencia, el conflicto provocó un fuerte impacto sobre la población civil: Colombia exhibía los índices más altos de violencia y los diez departamentos más afectados por la violencia reportaron 174.046 muertes. Las tácticas de los grupos armados, si bien se diferencian en ciertos casos, consistían en ataques frontales a la población civil, para alcanzar objetos de guerra, ocasionando así el desplazamiento de la población. (...) Roldán (2003) estima que, durante el periodo comprendido entre 1946 y 1966, 


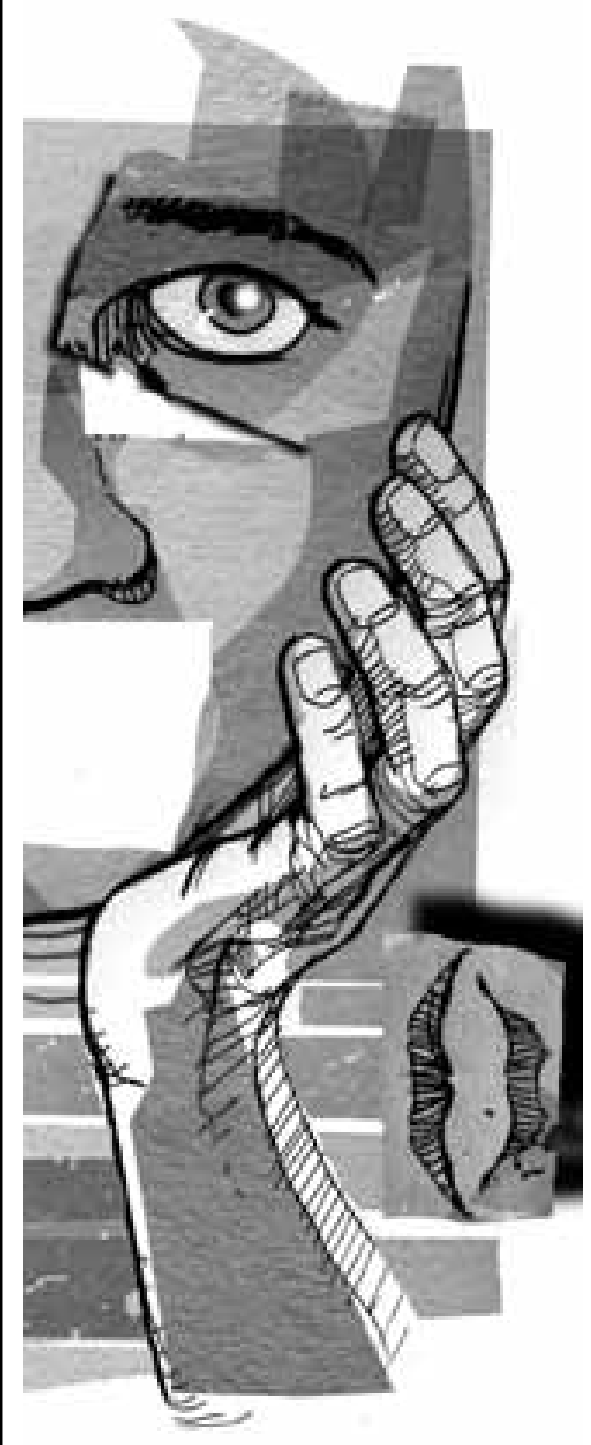

cerca de dos millones de colombianos migraron de manera involuntaria y un alto porcentaje nunca retornó. Los ataques a la población civil buscaban, como en la actualidad, fortalecer la hegemonía sobre un territorio, usurpar tierras valiosas y despejar las tierras de posibles oponentes". ${ }^{4}$

Las dinámicas y formas de agresión por parte de los grupos armados ilegales (o legales) han cambiado de acuerdo a las tácticas y modos de apropiación de las tierras o territorios. Las razones por las que los campesinos abandonan sus tierras ya no se limitan a los ataques directos que desplazaron en los últimos años a dos millones de colombianos, sino que, en la actualidad, basta con hostigamientos generales o la presencia -y su amenaza, la agresión potencial, siempre presta a concretarsede los agentes promotores del desplazamiento para producir nuevas oleadas de desplazamiento. De este modo, incluso aunque disminuyan las formas más visibles de hostigamiento y violencia sobre las poblaciones (masacres, asesinatos selectivos, confinamiento territorial), el desplazamiento forzado no cesa.

\section{La intervención social: el camino hacia los "sujetos de conocimiento"}

"La intervención en lo social va a significar el montaje de una nueva forma de conocer, de saber, en definitiva de generar discursos de verdad que construirán sujetos de conocimiento. En otras palabras, ese otro será constituido despaciosa y calladamente a través de descripciones, informes, observaciones y especialmente desde la relación que se establece con quien lleva adelante la intervención"

Aprovechando esta definición hablaremos de los "sujetos de conocimiento" que, según Carballeda, hacen referencia a ese "otro" que se quiere conocer. Para que se establezca un espacio de conocimiento debe existir un lugar en el que se relacionan todos los actores que, en palabras del autor, se define como escenario "(...) la noción de escenario remite a algo particular: es cambiante y también puede mudar dentro de una misma trama, es decir, dentro de un mismo guión (...)" Ese lugar cambiante está expuesto a situaciones que revelan que los "sujetos de conocimiento" no son simples receptores sino por el contrario vigilantes activos del proceso que se intenta construir a partir de ellos.

Es importante advertir que la intervención en lo social puede ser realizada a partir de cualquier disciplina que se proponga conocer y describir detalladamente a los "sujetos de conocimiento" que están inmersos en una situación social particular. La intervención social según Javier Corvalán supone "la inaceptabilidad de una situación vivencial de un grupo de individuos, la cual a su vez estaría provocada por la dinámica de base del sistema"”. Carballeda hace notar que esta intervención no necesariamente implica transformación radical de la situación vivencial: 
“Tal vez la intervención en lo social no implique agregar ni quitar nada sino solamente 'hacer ver' aquello que en el contexto, en el escenario, el clima de época impiden visualizar. Y acaso permita hacer que ese otro recupere historicidad, ubicándolo en el lugar de la verdad, corrigiéndolo del banquillo de la sospecha entendiendo que se es tanto efecto de la cultura que es imposible pensarse separado de los otros, y que la diferenciación estriba en lo singular de las inscripciones de cada cuerpo"

Hacer ver la complejidad del desplazamiento forzado y hacer ver aquello que la representación mediática impide ver sobre el fenómeno es, en este caso, el alcance de nuestra intervención social. Desde la Comunicación Social, a través de un enfoque etnográfico y reflexivo, se trataba de contrastar la situación de vida del grupo de mujeres, con los discursos e imágenes informativos sobre el desplazamiento forzado del noticiero del canal CARACOL ${ }^{9}$. Ese "hacer ver" no solo fue aprehendido por nosotras a través del proceso de intervención social sino por ellas, las participantes, que -en tanto sujetos sociales- poseen conocimientos y tienen demandas de saber que les permiten reconocer aquello que estiman relevante e importante para sus vidas.

Asumir la centralidad de la "visión del otro" supuso para nosotras entender que la dirección del proceso la llevaban ellas: nuestro papel era mantener el diálogo con ellas y analizar las razones por las cuáles el proceso de intervención iba tomando determinados rumbos y direcciones. Para ello era indispensable estudiar sus contextos de vida, sus relaciones, sus formas de actuar, aspectos que sólo nos fueron accesibles gracias a que ellas y nosotras compartíamos y participábamos del proceso de intervención, lo que implica -en ocasiones- intimar y poner en común nuestras vidas y las de ellas.

Entendimos que los sujetos sociales a pesar de su situación marginada, de su falta de comprensión experta y técnica de las problemáticas sociales, poseen conocimientos estratégicos, el saber de la alteridad, que desafía justamente las certidumbres del conocimiento experto. Al respecto, Carballeda sugiere que:

"En definitiva, la intervención en lo social implica una necesaria articulación entre la subjetividad y los procesos colectivos con un horizonte determinado: el de la problemática de la integración. Este proceso es accesible a través de la interpretación del acontecimiento, el análisis y el registro. Por último la intervención en lo social expresa la necesidad de una búsqueda, de una construcción de una modalidad discursiva diferente, determinada ahora por el sujeto, por su propia palabra, por su singularidad, a la vez que recupera la importancia de los vínculos de ese sujeto con otros, buscando desde allí una resemiotización de aquello que se construyó discursivamente como hegemónico. Una alteración de la gramática que permita una nueva enunciación de lo real”10 


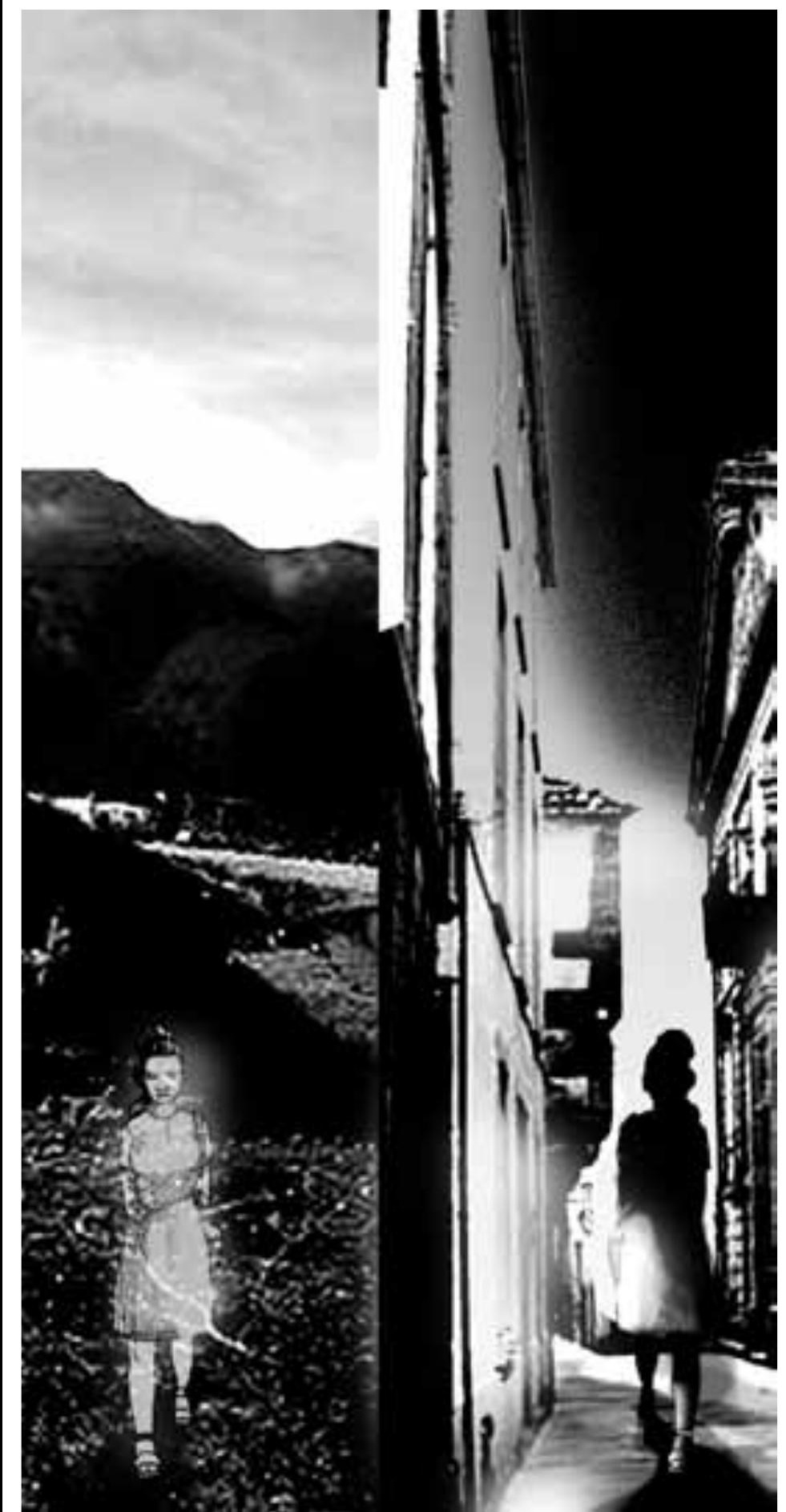

Fue muy relevante, en todo momento, la configuración del grupo de mujeres que acompañaron esta experiencia. Con sus saberes y experiencias, los modos de relacionarse entre ellas y con nosotras, de contar sus historias, de concebir la vida en comunidad, aportaron a la génesis de un espacio conversacional. En el proceso nos convertimos todos en una pequeña comunidad que generaba un espacio de reflexión sobre la condición de vida de estas mujeres en Cali en tanto desplazadas por la violencia y sobre lo que ellas pensaban acerca de las noticias de desplazamiento forzado que proyectamos en algunas sesiones. La forma en la que poco a poco nos fuimos compenetrando como grupo recuerda los lazos de fraternidad que ellas mismas tejían en cada una de sus comunidades. Ellas mismas lo manifestaron en varias ocasiones cuando hacían comparaciones entre la ciudad y sus lugares de origen, subrayando los vínculos afectivos y filiales de sus lugares de origen, y las dificultades que tenían para reeditar y establecer vínculos fraternos similares en la ciudad. Sus relatos y opiniones nos permitieron conocer un poco sus formas estrategias y formas de adaptación a la ciudad, la manera en que se desenvolvían sus vidas en los distintos lugares de procedencia en el Pacífico colombiano, la reelaboración que hacen de sus vidas desde el momento de desplazamiento forzado hasta su establecimiento obligado en Cali; sus planes de futuro y, sobre todo, de la valoración positiva de su identidad como mujeres afrocolombianas, con formas de vida y costumbres particulares significativas muy valiosas ${ }^{11}$. 


\section{Descripción de la metodología aplicada}

El abordaje etnográfico constituyó el modo de trabajo de campo para avanzar en el encuentro con los "sujetos de conocimiento". Compartimos la concepción que, de la etnografía, tiene Rosana Guber:

(...) un método abierto de investigación en terreno donde caben las encuestas, las técnicas no directivas -fundamentalmente, la observación participante y las entrevistas no dirigidas- y la residencia prolongada con los sujetos de estudio, la etnografía es el conjunto de actividades que suele designar como 'trabajo de campo', y cuyo resultado se emplea como evidencia para la descripción" $"$.

Para describir a los "sujetos de conocimiento" utilizamos la entrevista no dirigida, la observación participante y la entrevista etnográfica. El abordaje etnográfico implica, como señala Guber, realizar continuamente un trabajo de reflexividad, es decir supone "la conciencia del investigador sobre su persona y los condicionamientos sociales y políticos. Género, edad, pertenencia étnica, clase social, y afiliación política suelen reconocerse como parte del proceso de conocimiento vis-a-vis los pobladores o informantes"13. Vamos a detenernos en este punto con el objetivo de explicar nuestra relación como investigadoras sociales. Es importante describir que nuestra pertenencia sociocultural y nuestra pertenencia étnica juegan un papel relevante durante el proceso de intervención social. Ana Paola, siendo una mujer afrocolombiana y además perteneciente a la región del Pacífico, debería tener mucho sigilo en su relación con el grupo de mujeres, debido a que podría obviar aspectos relevantes. Los sobreentendidos y la mirada naturalizada compartida podían pasar por alto asuntos que no son obvios para todas las personas. Guber afirma: "Cuando el etnógrafo convive con los pobladores y participa en distintas instancias de sus vidas, se transforma funcional, no literalmente, en 'uno más' "14. El peligro de esa transformación "funcional" debía ser considerado en la interacción con los "sujetos de conocimiento". Pero la reflexividad no solo se refiere a esta condición de pertenencia social. Guber señala lo siguiente:

"Para que el investigador pueda describir la vida social que estudia incorporando la perspectiva de sus miembros, es necesario someter a continuo análisis -algunos dirían "vigilancia"- las tres reflexividades que están permanentemente en juego en el trabajo de campo; la reflexividad del investigador, con su perspectiva teórica, sus interlocutores académicos, sus hábitus disciplinarios y su epistemocentrismo; y las reflexividades de la población en estudio"15.

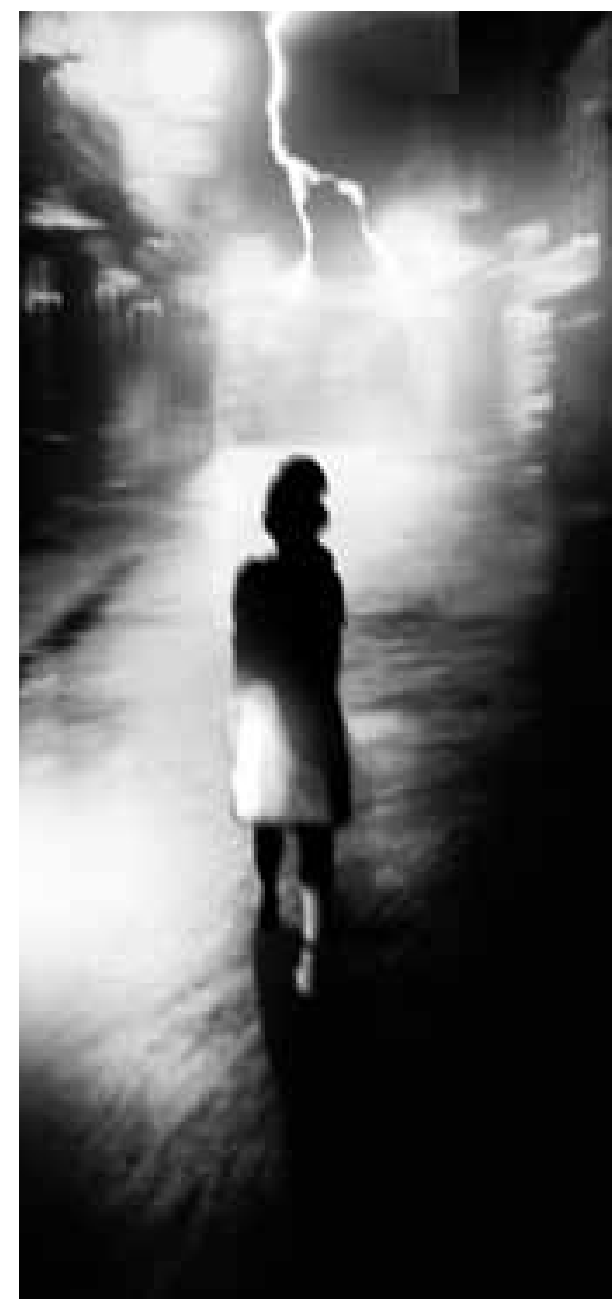


En cuanto a "la reflexividad del investigador y su perspectiva teórica" debíamos advertir que nuestra presencia podría influir en los comportamientos de las mujeres. Guber nos dice que: "La presencia del investigador constituye las situaciones de interacción, como el lenguaje constituye la realidad”. La presencia de Eliana, una mujer no negra que no proviene del Pacífico Colombiano, también podría ser conflictiva. Su reflexividad, "su perspectiva teórica”, debía ser mediada y examinada continuamente:

"El investigador puede predefinir un "campo" según sus intereses teóricos o su sentido común, "la villa", "la aldea”, pero el sentido último del "campo" lo dará la reflexividad de los nativos. (...) El desafío es entonces, transitar de la reflexividad propia de los nativos. ¿Cómo? En un comienzo no existe entre ellos reciprocidad de sentido con respecto a sus acciones y nociones (Holy\&Stuchlik, citados por Guber, $1983: 119)^{16}$

En suma, la reflexividad hace parte fundamental en las experiencias que vive y descubre el investigador en su relación con los objetos y sujetos de su investigación, y los logros y alcances de esa relación son producto de ese intercambio de conocimientos.

Por otro lado, la observación participante "consiste en dos actividades principales: observar sistemática y controladamente todo lo que acontece en torno al

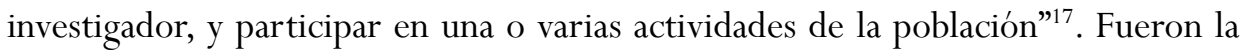
observación y la participación fundamentales para la descripción de los "sujetos de conocimiento". Para lograr esto, visitamos a las mujeres protagonistas de la investigación, en ocasiones distintas a las programadas para las sesiones; a través de estos encuentros, pretendíamos entenderlas en su relación familiar con su contexto primario $^{18}$. Nuestra participación se vio representada en las sesiones; las actividades, en ocasiones, eran realizadas conjuntamente con ellas. Guber señala que:

“(...) la observación y participación suministran perspectivas diferentes sobre la misma realidad, aunque estas diferencias sean más analíticas que reales. Si bien ambas tienen sus particularidades y proveen información diversa por canales alternativos, es preciso justipreciar los verdaderos alcances de estas diferencias; ni el investigador puede ser 'uno más' entre los nativos, ni su presencia puede ser tan externa como para no afectar en modo alguno el escenario y sus protagonistas." ${ }^{19}$

En algunos momentos del trabajo de campo optamos por la "entrevista no dirigida": "En las [entrevistas] no dirigidas, en cambio, solicita al informante indicios para descubrir los accesos a su universo cultural. (...) al iniciar su contacto el investigador lleva consigo algunas preguntas que provienen de sus intereses más generales y de su investigación”20. De esta forma logramos realizar el esquema de preguntas que desarrollaríamos en las entrevistas etnográficas (o entrevistas en profundidad). Estas estrategias fueron implementadas en algunas de las sesiones al poner un tema en común ${ }^{21}$, abierto, y registrar sus reacciones, comentarios y relatos.. 
"La entrevista es una estrategia para hacer que la gente hable sobre lo que sabe, piensa y cree (Spradley 1979, citado por Guber, p. 9) (...) Esta información suele referirse a la biografía, al sentido de los hechos, a sentimientos, opiniones y emociones, a las normas o estándar de acción, y a los valores o conductas ideales"22. Como sabíamos que a través de las sesiones y las visitas domiciliarias no lograríamos conocer ampliamente la situación de vida de las mujeres que nos acompañaron en el proceso, decidimos entrevistarlas.

No solo se trataría de la narración de su momento de desplazamiento forzado. Son personas pertenecientes a una cultura que fue gravemente quebrantada al iniciar el éxodo forzoso a la ciudad. ¿Cómo conseguir que hablaran y ofrecieran testimonios de un evento profundamente traumático? Según Beatriz Sarlo: "No hay testimonio sin experiencia, pero tampoco hay experiencia sin narración: El lenguaje libera lo mudo de la experiencia, la redime de su inmediatez o de su olvido y la convierte en lo comunicable, es decir, lo común”. ${ }^{23}$

Debíamos crear las condiciones adecuadas para que esta vivencia traumática pudiera derivar en relato, en algo comunicable, en testimonio de un contexto crispado por la violencia en una época y lugar determinados. Pero además deberíamos tener mucho cuidado y ser particularmente respetuosas y, al mismo tiempo, cautas. La advertencia de Sarlo es clave: "Todo testimonio quiere ser creído y, sin embargo, no lleva en sí mismo las pruebas por las cuales puede comprobarse su veracidad, sino que ellas deben venir desde afuera." ${ }^{24}$

Esa "relación social" debía ser construida bajo unas condiciones que garantizaran un resultado favorable a la investigación y con el mayor respeto a los "sujetos sociales". Tanto el entrevistador como el entrevistado influyen en el desarrollo de una entrevista. Guber explica lo siguiente: "El entrevistado no ingresa a la entrevista dejando atrás las "normas que guían otros tipos de eventos de comunicación", de manera que puede ocurrir que "las normas (que gobiernan su propia comunidad comunicativa) están en oposición a las que surgen de la entrevista” ${ }^{25}$. Por esta razón el investigador: "(...) debe empezar por reconocer su propio marco interpretativo acerca de lo que estudiará, diferenciándolo en conceptos y terminología, del marco de los entrevistados; este reconocimiento puede hacerse revelando las respuestas subyacentes a ciertas preguntas y al rol que el informante le asigna al investigador" 26 .

Tratamos de seguir un esquema de preguntas y un temario, lo que no es incompatible con el carácter emergente y no completamente previsible de una conversación y una entrevista. Guber, de nuevo, ofrece sugerentes indicaciones al respecto: "El investigador necesita partir de una temática predeterminada que será provisoria hasta tanto la vincule o la sustituya por otros temas más significativos (...) Aceptar esta provisoriedad permite abrir la percepción a temas aparentemente inconexos, sin interpretarlos como elusiones, desvíos o pérdidas de tiempo"27. 
Considerando que uno de los temas de la entrevista sería el momento de desplazamiento forzado tendríamos que saber cómo, cuándo y dónde hacer las entrevistas. Pretendíamos realizar todas las entrevistas en los lugares de residencia de las mujeres; sin embargo hay que tener en cuenta que la mayoría de ellas no poseía un lugar propio y, como indicamos antes, tenían con sus lugares de residencia un cierto extrañamiento, tan distinto a la relación de entrañamiento que supone un hogar. Sus residencias actuales constituyen una especie de "limbo" y lugar de tránsito, entorno provisional que -con el paso de los días, conforme se prolonga el exilio- va poblándose de objetos que demarcan y anclan la vida, haciéndolos menos provisionales, menos transitorios. De otro lado, era importante considerar que, incluso en aquellos casos en que la mujer conversa sobre su vida en un lugar que siente suyo, el tipo de restricciones, controles y sujeciones que se viven en casa: "si bien la entrevista etnográfica suele hacerse en el medio habitual del entrevistado, esto no siempre es una ventaja. Si la informante se siente controlada por su marido puede ser conveniente buscar otros ámbitos más 'neutrales' ". ${ }^{28}$

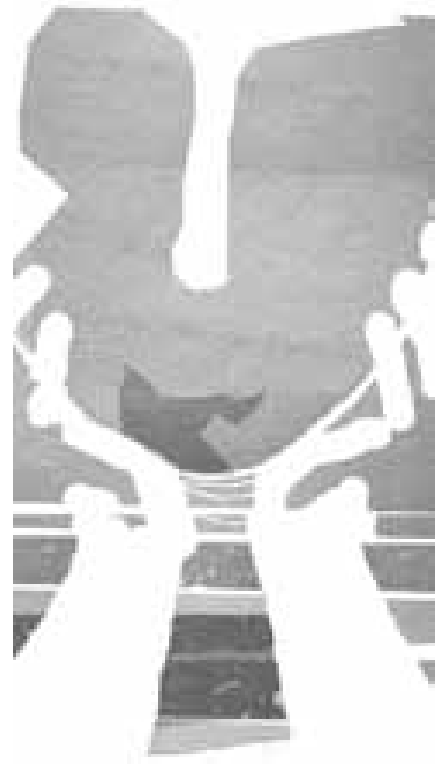

\section{Sobre la construcción de los espacios de discusión y debate}

Para la construcción de los espacios de discusión en torno al tema del desplazamiento forzado y su tratamiento mediático, y la socialización de aspectos sobre cada una de las experiencias de vida de las mujeres participantes, decidimos inscribirnos en la modalidad de taller reflexivo (Gutiérrez, 2003):

"El taller reflexivo constituye un dispositivo de palabra en el que se construyen grupalmente planteamientos, propuestas, respuestas, preguntas e inquietudes respecto a un tema subjetivo. Para el logro de dicha construcción, el tallerista se sitúa en 'el lugar de la escucha (activa)' y le brinda la palabra al grupo. Esto tiene como objetivos 'movilizar' a los participantes respecto a su subjetividad, 'propiciar la ventilación' de sus sentimientos negativos, 'esclarecer saberes' o posiciones específicas y 'responsabilizarlos' en la construcción de opciones respecto a dichos saberes." 29

Se trataba de la "construcción" de un espacio en el que ellas serían las protagonistas. Por esta razón, aunque habíamos previsto el uso, sobre todo, de recursos audiovisuales y visuales para propiciar las conversaciones, estas debían ser consultadas, acordadas y concertadas, no dirigidas e impuestas por nosotras:

"En el taller (...) el coordinador sólo llega con unas herramientas como el sociodrama, la reflexión en subgrupos, etc., con las cuales pone en movimiento el proceso de construcción grupal. A partir de este punto, el producto se va construyendo paulatinamente entre todos. El tallerista y todos los asistentes se hacen responsables de la elaboración del producto, todos 'trabajan'." 30 
Cuando empezamos el proyecto, no tuvimos en cuenta la naturaleza dialógica de este tipo de experiencias de intervención. Por eso, al comienzo, nos estrellamos con un muro de silencios, desconfianzas y malentendidos desafortunados. Debido a los hábitos de la vida escolar universitaria, los hábitos del docto y del experto, en la primera sesión presentamos de manera unilateral un resumen sobre el desplazamiento forzado expuesto de forma académica. De esta manera nos situábamos a nosotros mismas en el centro de la dinámica de intervención, la posición directiva y omnipotente del que se presume sabio. El experto "asume el 'lugar de la omnipotencia' (aquel en que se debe, puede o tiene que hacer todo)" (Gutiérrez, 2003: 23). Olvidamos que no hay relato y conversación si no se disponen de las condiciones adecuadas de diálogo e interacción, esto es, si no hay una relación mutua de consentimiento y colaboración: "el tallerista asume el lugar de la 'colaboración' (se desarrolla la labor con los otros), el lugar de la 'construcción”’”31.

Tras examinar la sesión \#1 y las dificultades con que topamos, en los posteriores encuentros utilizamos estrategias que movilizaban la participación del grupo. En la sesión \#2, a través de la inducción de recuerdos sobre el lugar de origen, motivamos la exposición de las experiencias de vida y la reflexión sobre su pasado antes del desplazamiento forzado. Además, utilizando una pieza noticiosa sobre desplazamiento forzado, abrimos el debate para escuchar sus percepciones personales sobre el audiovisual. La misma estrategia fue utilizada en la sesión \#3, incluimos la utilización de fotos que aludían a los distintos lugares del Pacífico como dispositivo para recordar nuevamente aspectos vivenciales sobre los lugares de donde provenían. Ya en el cuarto encuentro, construimos un "foro" de discusión que pretendía exponer las opiniones de dos (2) periodistas ${ }^{32}$ invitados con las de las mujeres participantes para que ellas conocieran aspectos sobre la elaboración del discurso informativo televisivo. En la quinta sesión, para remitirnos a las prácticas culturales del Pacífico, en este caso la culinaria, propusimos la elaboración de un plato de la región Pacífica. Esta preparación incluyó la participación de las mujeres y una de nosotras medio en ese momento. De esta manera construimos un espacio de tertulia y cocina que arrojó conocimientos sobre sus distintos lugares de origen. Finalmente, en el sexto encuentro, compartimos un relato que remitía a historias del Pacífico colombiano para conocer sus percepciones sobre la vida en comunidad y escuchar sus visiones acerca de las diferencias que hay entre sus vidas antes del desplazamiento y su residencia actual en la ciudad.

Todas estas estrategias fueron elaboradas cuidadosamente teniendo en cuenta los objetivos de la investigación. Gutiérrez las llama "dinámicas de contenido" o "tareas" y las define como "Juegos orientados a la reflexión sobre el tema" ${ }^{33}$. 


\section{Análisis general sobre las experiencias de los "sujetos de conocimiento"}

Consideramos que la metodología facilitó el encuentro y socialización de experiencias de vida y experiencias mediáticas. Hubo algunas dificultades y tropiezos, pero se configuró un espacio de discusión, intercambio y debate real que favoreció el cumplimiento de nuestro propósito de estudio, incluso más allá de los objetivos trazados inicialmente.

Maritza, Elodia, María y Beatriz hacen parte de este grupo de desplazados por el conflicto armado. Ellas abandonaron su lugar de origen porque en la zona donde residían había presencia guerrillera, paramilitar y de ejércitos estatales (en el caso de las fumigaciones que desarrollaban en el marco del Plan Colombia, en el Río Mejicano, Nariño).

Marcia y Antonia lo hicieron también por estas razones, pero además tuvieron que enfrentar amenazas directas sobre la vida de alguno de sus familiares. El hijo de Antonia es objeto de un atentado directo por el grupo de las Águilas Negras o Los Rastrojos. "Las mujeres pueden ser víctimas directas o colaterales de distintas formas de violencia, como resultado de sus relaciones afectivas como hijas, madres, esposas compañeras o hermanas" ${ }^{34}$.

Sobre su infancia, la niñez, la adolescencia y la vida en familia en los lugares de origen, encontramos que comparten algunas actividades y rutinas similares, tareas de las que se ocupan, en particular, las niñas: playar, conchar, pescar, cocinar, trabajar en agricultura y minería.

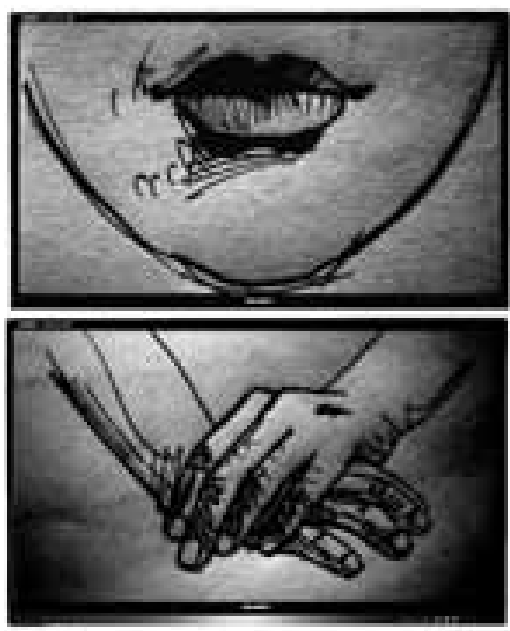

Maritza, aunque tuvo que hacer muchas de estas actividades, tal vez por ser la más joven del grupo, tuvo educación formal básica. Esta escolaridad ha sido clave para su "adaptación en la ciudad".

Beatriz manifiesta haber sufrido discriminación, abandono, racismo, maltratos físicos y morales en la ciudad. Se trata de un despojo doble: el del lugar de origen y el de un clima generalizado de agresión en el lugar de llegada. "La CIDH ha podido corroborar que la situación de las mujeres indígenas y afrocolombianas es particularmente crítica al ser víctimas de múltiples formas de discriminación por causa de su raza, etnia y por el hecho de ser mujeres, situación que se agrava dentro del ámbito del conflicto armado." 35

Aunque Beatriz es quien expresa con mayor vehemencia haber vivido maltrato directo, derivado además de otras violencias como la de género o la intolerancia racial, las demás han padecido agresiones y violencias sensibles en Cali y en sus lugares de origen. Por ejemplo, Maritza fue víctima de hostigamientos que han afectado de su salud.

A Marcia la guerrilla amenazó con reclutar a uno de sus hijos mayores, y experimentó muchas veces la zozobra de incursión militar de la organización subversiva: prefirió abandonar su población. "Las familias pueden migrar de manera involuntaria, para evitar el reclutamiento forzoso de sus hijos por parte de los grupos armados al margen de la Ley". ${ }^{36}$

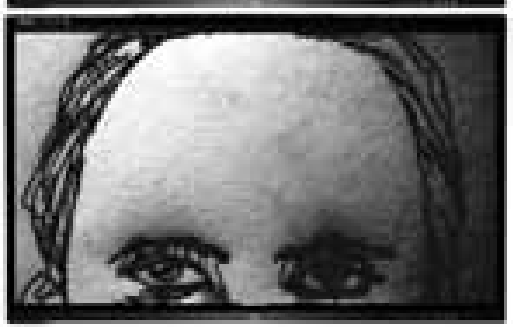


Después de inscribirse forzosamente a las cifras de colombianos en condición de desplazamiento por la violencia, estas mujeres llegan a Cali en compañía de sus familias; exactamente al barrio Pízamos I, un sitio marginal perteneciente al Distrito de Aguablanca, poblado por familias que viven en extrema pobreza y donde encuentran a otros desplazados por la violencia provenientes de distintas regiones. Este detalle es crucial: no se llega a Cali, se llega a un zona particular y específica de la ciudad. En consecuencia, van emergiendo "barrios, comunas y distritos de desplazados en las grandes ciudades, y concluir que los desplazados no van a las grandes ciudades en general, sino a ciertos lugares de extrema concentración de pobreza, que están dentro de esas ciudades, pero fuera de ellos en términos sociales económicos y físicos" ${ }^{\text {"37. }}$.

Esta relación geográfica y social con la ciudad de Cali no es gratuita, muchos desplazados por la violencia o desplazados a voluntad se ven obligados a asentarse en ciudades y localidades más grandes que aquellas donde residían inicialmente. En la mayoría de los casos han contado con algún contacto, amigos o familiares, en el lugar de llegada. Es una constante en las seis experiencias que nos atañen: todas llegaron a esta ciudad y especialmente a este barrio porque cuentan algún contacto establecido allí: "Los individuos deciden a dónde ir dependiendo del alcance máximo de sus redes sociales y de lo que han hecho otros individuos en el pasado. Es cierto que buscan nodos situados más arriba en el orden espacial, pero a cuál irán depende en forma crucial de la información que reciban a través de sus redes sociales. ${ }^{38}$

Las personas en situación de desplazamiento escogen como su ciudad refugio o municipio receptor al más grande en cantidad de habitantes y con mayores ofertas laborales, pero esta escogencia es limitada por la distancia. Cali se convierte en la ciudad receptora de municipios como Cauca y Nariño.

Así "la división entre el centro y la periferia, que separaba a los habitantes del campo, de los de la ciudad, es transferida a las grandes ciudades en la forma de asentamientos de desplazados situados en la extrema periferia social y económica de las ciudades" ${ }^{39}$. Por ello no es coincidencia la ubicación de desplazados en zonas como el Distrito de Aguablanca y las Laderas de Cali. De esta forma este grupo social se articula a la ciudad periférica y no a la ciudad central, con sus restricciones y exclusiones sociales, económicas, laborales, educativas y de recreación. Elodia, Maritza y María sólo conocen el lugar donde viven, es decir, sus relaciones con los habitantes de la ciudad integrada se reducen a meros contactos contigentes.

Situadas en los barrios humildes, periféricos y emergentes de la ciudad, a su condición de desplazamiento se añade su condición de marginalidad en Cali. María, Antonia, Marcia y Maritza se declararon como desplazadas por el conflicto armado; unas en el municipio de Nariño y otras en Cali. Al estudiar las regulaciones legales para su condición, se puede apreciar la precaria y limitada intermediación estatal para atender la inserción social del desplazado en el lugar de recepción:

"[El desplazado tiene derecho a] Tener respuesta a su declaración en 20 días aproximadamente, volver a su tierra o reubicarse en otro lugar, si es que no puede volver pronto; a tener documentos de identidad nuevamente, si los perdió en su desplazamiento; a recibir atención humanitaria de emergencia que consiste en una ayuda económica. Después de inscribirse en la UAO (Unidad de Atención y Orientación al Desplazado), tiene derecho a 3 meses de ayuda económica, derecho a la educación gratuita, derecho a una vivienda digna, derecho al trabajo, derecho a la seguridad y protección, derecho a la salud". ${ }^{40}$

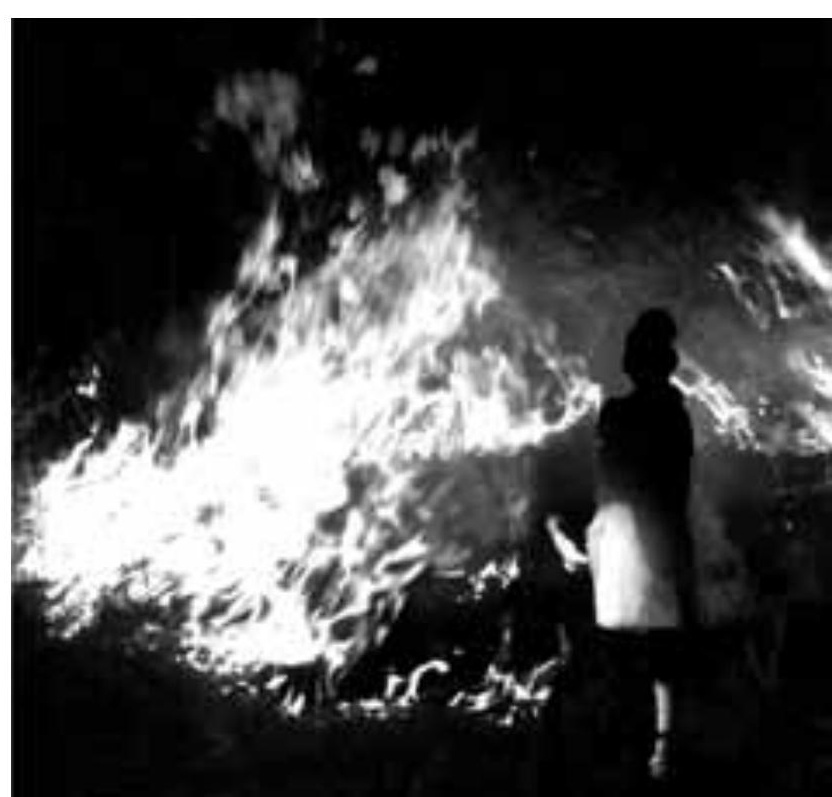


Por lo menos ocho de los anteriores derechos les han sido negados a cada una de ellas. En el caso de Beatriz y Elodia, que no se declararon desplazadas forzadas, pues creían que su condición no lo ameritaba, la situación es aun más desalentadora. Las declaraciones legales y generales, no parecen traducirse en acciones y soluciones concretas para ellas. "El Estado tiene la obligación de brindar una protección especial a mujeres que estén particularmente expuestas a actos de violencia por ser menores de edad, por ser afrodescendientes, por ser indígenas, por haber sido desplazadas y/o por haber sido directamente afectadas por el conflicto armado"41 .

La principal preocupación que tienen estas seis mujeres está enfocada en el bienestar de su familia, en cuanto a su seguridad y a su estabilidad económica. Viven diariamente sin tener empleo, vivienda o condiciones mínimas para alimentarse, y mucho menos para procurar la atención pública y estatal a que tienen derecho. Supervivencia sin ciudadanía, dice Salazar:

“Todos los fenómenos y estructuras mencionados hacen parte de un sistema más amplio que 'toma' a los más débiles y pobres del campo y los envía, mediante la guerra a la periferia de las ciudades y transforma, de paso, las estructuras regionales y urbanas, generando una nueva clase de colombianos que sobreviven en la condición que Giorgio Agamben (1998) denomina como la vida desnuda (Baralife): la pura superfivencia sin ciudadanía" ${ }^{32}$.

Entonces, para sobrevivir, adecúan sus prácticas culturales de producción económica como un capital intangible que usufructuar en un espacio social distinto a aquel en las aprendieron y ejercieron toda la vida. Beatriz está aprovechando su conocimiento culinario. Desarrolla sus aptitudes, hace y vende en comidas típicas para poder sostenerse Gracias a su liderazgo convence a Marcia de hacer lo mismo. Antonia comercia verduras y frutas.

Maritza intenta hacer algo similar vendiendo chontaduro: es "platonera" en un centro comercial de la ciudad. Pero resiente el desprecio de los caleños en el Centro Comercial donde vende: sabe, dice, que la observan con desprecio, se siente menospreciada. He aquí una experiencia distinta del no lugar a la que sugiere Augé. Si para los consumidores de clase media, el Centro Comercial es un no lugar, para Maritza es la prolongación de su estado de limbo, no tener un lugar. El "limbo socioespacial” en el cual se encuentran estas mujeres está hecho, por un lado, de la ciudad -la central- que no es la suya, y por otro lado, de la residencia-la de los barrios humildes y periféricos- en préstamo, todo lo anterior con el trasfondo fantasmal del lugar propio, pero lejano y despojado. Al vivir la ciudad como un territorio que no es el suyo, deben inventarse y habitar todos los días ese limbo, provisional, precario, indefinido, donde aprovechar - para sobrevivir- aquellos saberes que, en su territorio, eran prácticas vívidas y sobresabidas. De esta manera un sitio como el Centro comercial, ese no lugar para los habitantes de la ciudad normalizada, está en una oposición directa, para Maritza, con su lugar de origen, ese lugar donde ser negra no es una marca de diferencia - despreciada por algunos de que transitan por el Centro Comercial. El Centro Comercial donde vende el chontaduro, se le presenta como 
un lugar aséptico, en el que no traba relaciones significativas con nadie, y en el que casi no habla. Durante las sesiones taller, Maritza va comprendiendo la dignidad de su trabajo, de su lugar de procedencia y de su condición de mujer afrocolombiana. El desprecio que percibe en el Centro Comercial contrasta con la mutua y solidaria dignificación que experimenta al hablar de estas cosas con otras mujeres que, como ella, han encarado estas formas de desprecio y han padecido desplazamiento forzado.

María y sus seis hijas están en una especie de "limbo", aún más profundo. Ellas adquirieron un conocimiento exclusivo para ser desarrollado en su lugar de origen. Tal vez sea muy difícil su adecuación a las dinámicas de la ciudad. Trabajaban tambando oro en el río, pescando y ejerciendo la agricultura.

"La situación de las mujeres afrocolombianas de la Costa Pacífica revela el confinamiento de las mujeres afrocolombianas rurales al ámbito de lo doméstico como un hecho histórico, como eje de su grupo familiar y de las relaciones directas con sus hijos y familiares:

Las mujeres afrocolombianas se inscriben en un patrón social que les asigna el rol de cuidadoras, las labores del ámbito doméstico son su responsabilidad, así mismo, la movilidad masculina que se opone a la permanencia femenina se asume como una forma de complementariedad de roles; las normas de comportamiento para hombres y mujeres son diferentes" ${ }^{\text {"33 }}$.

A través del desplazamiento forzado hacia la ciudad, algunas de estas mujeres pasan de ser amas de casa en el campo para convertirse en trabajadoras asalariadas en Cali. Maritza, Marcia, María y Elodia no han podido establecer una economía digna. Beatriz y Antonia lo han hecho, con muchas dificultades, y se han convertido en mujeres cabeza de familia que sostienen económicamente a sus familias.

A pesar de que estas seis mujeres y sus familias han tenido que afrontar todas las pérdidas dolorosas y traumáticas, cinco de ellas no piensan retornar, planean su futuro en Cali. Afirman que en sus lugares de origen no tienen la seguridad y tranquilidad necesarias. Beatriz, en cambio, planea envejecer en un lugar similar al de su procedencia, en el campo.

Según Ibáñez (2008), un desplazado puede tardar hasta 10 años en recibir oportunidades laborales y económicas iguales o superiores a las que reciben los nativos de una ciudad. Estas mujeres nos enseñan que el territorio es muy importante para establecerse dignamente como persona. Si el desplazamiento forzado produce la desestructuración del nicho en que la vida de la persona tiene sentido, construir y hacerse a un territorio que pueda vivirse y experimentarse como propio es exactamente el proceso inverso, reparador y atenuador del desplazamiento forzado. El desplazamiento por la violencia no es sólo cuestión de cifras, hay un laborioso trabajo de invención, recreación de mejoría, articulación de vínculos, reorganización de la propia experiencia, readaptación de saberes y prácticas, resemantización y resignificación de la identidad, cuestiones que afloran y se advierten bien cuando se asume que el desplazado es, sobre todo, un sujeto, un sujeto de conocimiento, que difícilmente puede reducirse a las declaraciones exotistas y esquemáticas con que se los representa en los noticieros o en la prédica asistencialista de algunas de las instituciones públicas y privadas que los apoyan. 


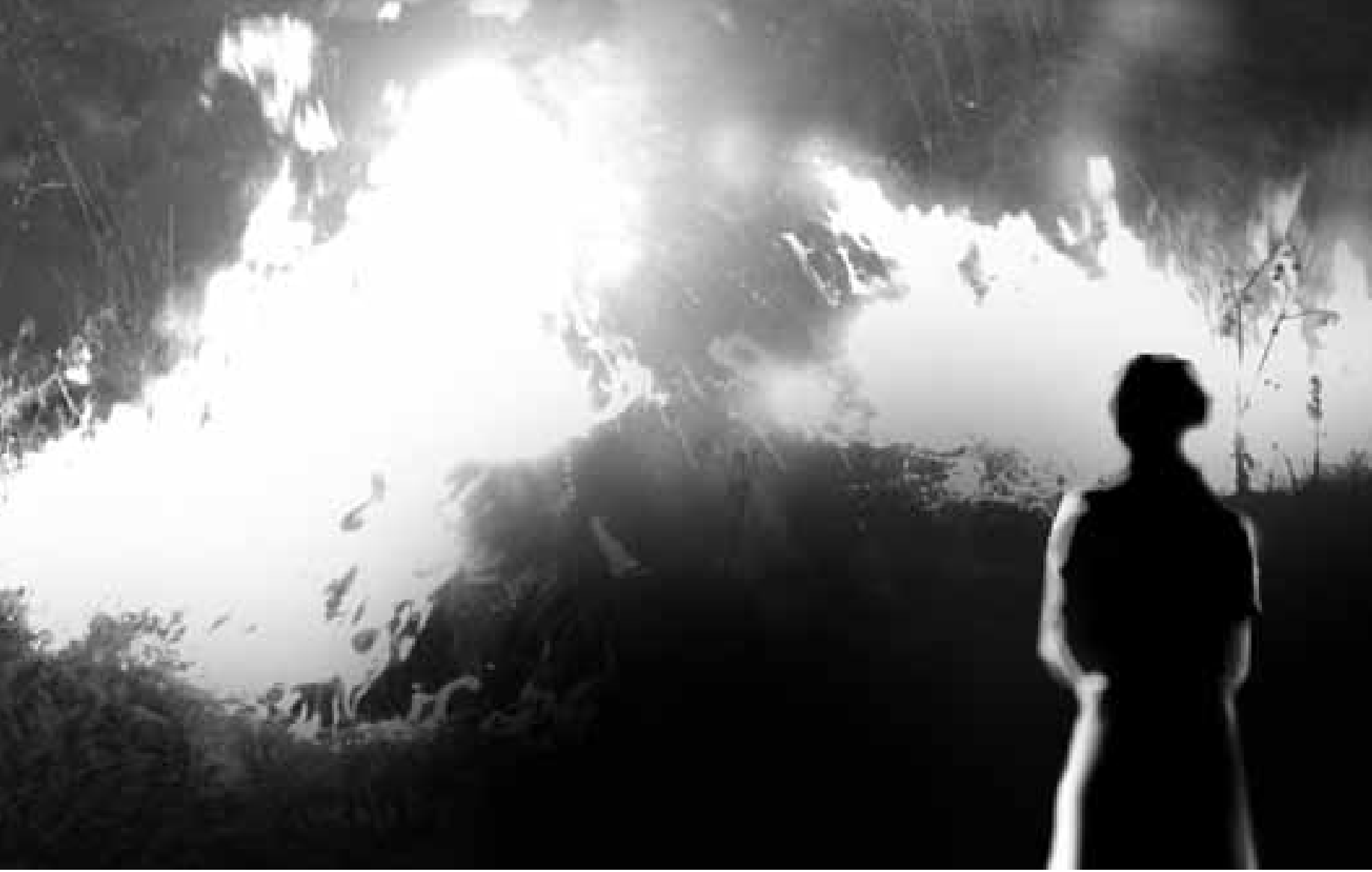

Conclusiones generales de la investigación teórica y el proyecto ejecutado

Existe una distancia significativa entre lo que se emite en el escenario mediático televisivo y las situaciones que han tenido que enfrentar este grupo de mujeres desde su desplazamiento hasta su progresiva adaptación a la ciudad. En tanto los noticieros se ocupan de documentar el hecho, el momento del desplazamiento, el evento noticiable, los aspectos cruciales para entender la compleja experiencia del desplazamiento, esto es, aquellas formas de vida previas al desplazamiento y aquello que deben inventar y crear para adaptarse a los lugares de recepción, no se registran en los medios. Sin dar cuenta de la densidad biográfica del sujeto antes y después de la situación de desplazamiento, la representación que crean los medios, en particular los informativos noticiosos en televisión, reduce al desplazado, en el mejor de los casos, a víctima y en el peor de los casos, en amenaza potencial para la estabilidad de la vida en los lugares de recepción.

Por medio de los recursos audiovisuales que contenían piezas noticiosas sobre el desplazamiento forzado, tuvieron la oportunidad de enfrentarse con un discurso que desde su punto de vista no refleja fundamentalmente lo que ellas y sus familias han tenido que enfrentar. Dejar sus vidas previas, asistir a periodos prolongados en una suerte de limbo socioespacial, readaptar saberes y prácticas para sobrevivir en la ciudad, renunciar - en algunos casos- a la idea de retorno al lugar de origen, todos procesos que permiten comprender que no se trata de desplazados, sino sobre todo- de sujetos en situación de desplazamiento, que están procurándose un lugar mínimamente digno en la ciudad. 
Los relatos de estas mujeres dan cuenta de una historia del conflicto armado que no es revelada fielmente por los hacedores de las noticias en televisión; y las consecuencias de esta forma de hacer noticias no son inocentes: a partir de esta información, se estigmatiza, prejuzga y desprecia al sujeto en situación de desplazamiento y se trivializa el desplazamiento, reduciéndolo o asociándolo a "problemas de inseguridad" o "problema asistencial y de caridad". Adicionalmente, los informativos no contribuyen a destacar la condición de los sujetos en situación de desplazamiento como personas sujetas de derecho dado que la vulneración de sus condiciones de vida y la amenaza sobre su porvenir es mucho particularmente grave.

A pesar de que en el proceso de intervención social intentamos un abordaje en que ellas analizan y examinan los contenidos informativos de los noticieros, es interesante notar que, sin excepción, no ven noticias. Estas víctimas del desplazamiento forzado no consumen la información mediática que las nombra y relata. Este fenómeno es muy significativo e indica dos desafíos que debería tener en cuenta la prensa y periodismo colombianos: en primer lugar, se requiere de noticias contextuadas, mesuradas y responsables en que la voz de los sujetos en situación de desplazamiento sea tenida en cuenta; pero, en segundo lugar, es importante construir relatos informativos y análisis periodísticos que contribuyan a eliminar y transformar la representación estereotipada que, sobre los desplazados, hay en los ciudadanos comunes y, más grave aún, entre las personas (funcionarios, agentes del estado, profesionales y expertos, diseñadores de políticas públicas) que toman decisiones.

La construcción de este tipo de espacios de deliberación y debate permite una revaloración y autovaloración de las personas. La puesta en común de experiencias $\mathrm{y}$ vivencias que afectan a las personas en situación de desplazamiento, puede contribuir a ampliar su interés por adelantar acciones públicas y sociales a favor de sus derechos y reivindicaciones.

Esperamos que este proyecto de investigación estimule a las escuelas de Comunicación Social a estimular la intervención social en comunicación como un tipo de tarea y responsabilidad profesional valiosa, en la que como profesionales- podemos hacer contribuciones significativas.
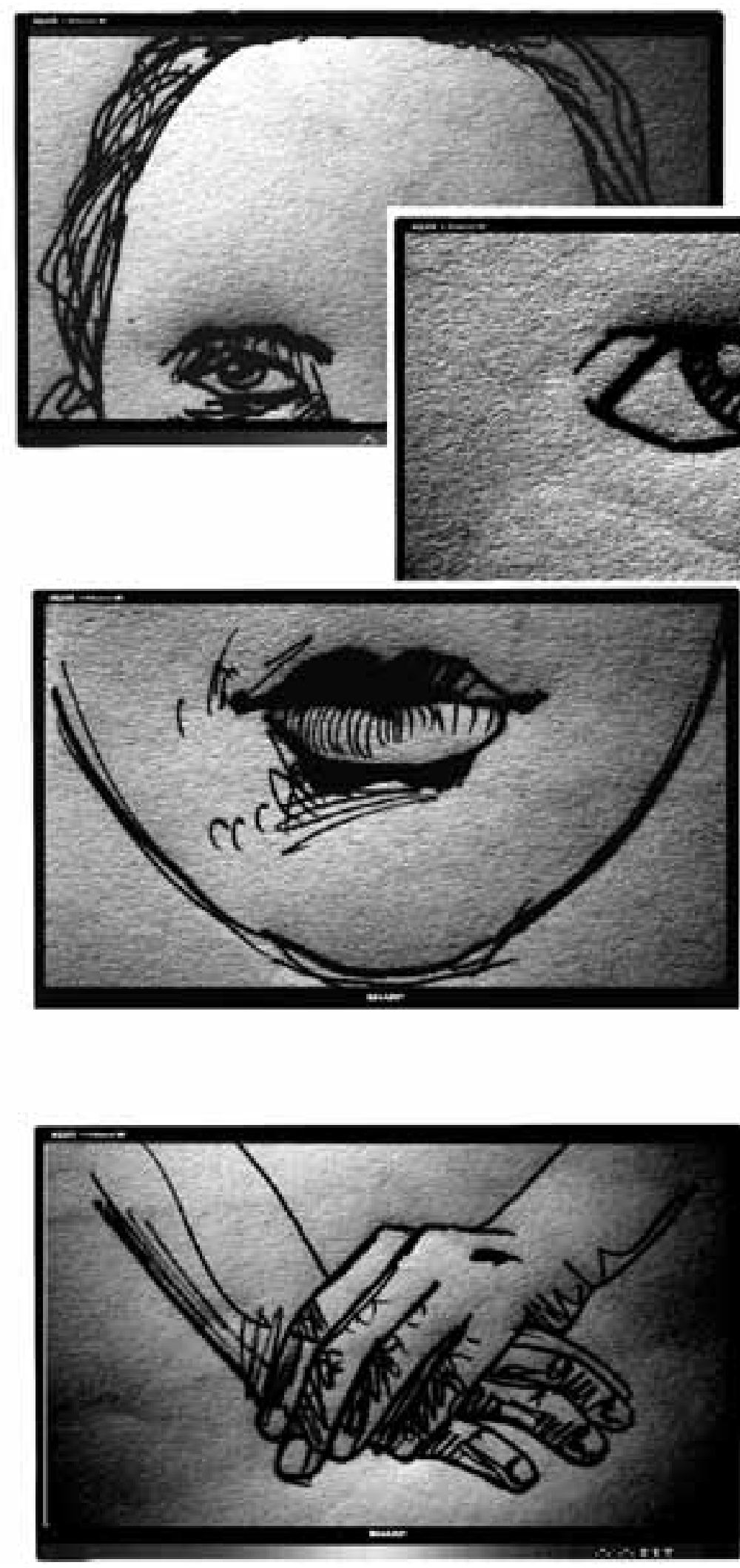


\section{Notas}

${ }^{1}$ Este estudio derivó en la tesis de pregrado de las autoras, en Comunicación Social.

2 BARNEY, Ernesto (2008). Cátedra de Desplazamiento Forzado, Impactos Sicosociales del

Desplazamiento Forzado, Módulos 6, 7a , 7b y 7c. P/UPC - ACNUR - Universidad Nacional de

Colombia. (CD ROOM)

${ }^{3}$ IBAÑEZ, Ana María. (2008). El desplazamiento forzado en Colombia: Un camino sin retorno hacia la pobreza. Colección Cede 50 años. Universidad de los Andes. (pp. 18-19).

${ }^{4}$ CARBALLEDA Alfredo J. (2002) "La Intervención en lo social: exclusión e integración en los nuevos escenarios sociales". Buenos Aires. Editorial Paidós SAICF y Tatanka S.A. p. 26

5 Ibíd., p. 57

${ }^{6}$ Ibíd., p. 5

${ }^{7}$ CARBALLEDA, Op. cit., p. 32

${ }^{8}$ Además de este material audiovisual del noticiero, utilizamos otras producciones audiovisuales alternativas que ofrecen abordajes y perspectivas diferentes a las del tratamiento informativo convencional.

${ }^{9}$ CARBALlEDA, Op. cit., p. 111

10 Cabe anotar que "afrocolombianas" y "del Pacífico" son términos que, en ocasiones, escamotean la enorme diversidad real del mundo social que designan. Pudimos conocer que existen grandes diferencias significativas formas de vida, costumbres y prácticas culturales entre poblaciones del Pacífico, cultural y geográficamente muy próximas. Algunas de esas diferencias se expresan, por ejemplo, en las comidas, tal como lo revelaron ellas cuando- en una de las sesiones- se obsequiaron mutuamente platos preparadas por ellas. Ventilaron animadamente las sutiles, pero importantes diferencias entre modos de cocción y sabores.

${ }^{11}$ GUBER, Rosana. (2001). La Etnografía, Método, Campo y Reflexividad. Bogotá, 2001. Grupo Editorial Norma. p. 16.

12 Ibíd., p.48

13 Ibíd., p. 50

14 Ibíd., p. 49

15 Ibíd., p. 52

${ }^{16}$ Ibíd., p. 57

${ }^{17}$ Nuestra intención era conocer sus lugares de residencia; sus objetos; la descripción de su hogar. Pudimos darnos cuenta que todas, a excepción de Beatriz, estaban obligadas a pagar arriendo. Esa situación configuraba sus hogares como lugares fríos y distantes, ajenos. La relación con el espacio hogareño era bastante traumática; notamos que no había sentido de pertenencia ni siquiera en Beatriz, que posee casa propia.

18 GUBER, Op. cit., p. 58

19 Ibid., p. 82

${ }^{20}$ Lo común concierne a sus lugares de origen y las formas como se desarrollaba su vida en cada uno de sus pueblos en el Pacífico.

21 . GUBER, Op. cit., p. 75

22 SARLO, Beatriz. (2007). Tiempo Pasado Cultura de la memoria y giro subjetivo. Una discusión. Argentina S.A. Siglo veintiuno Editores. p. 29.

${ }^{23}$ Ibíd., p. 47.

${ }^{24}$ GUBER, Op. cit., p. 78

${ }^{25}$ Ibíd., p. 80

${ }^{26}$ Ibíd., p. 86

${ }^{27}$ Ibíd., p. 99

${ }^{28}$ GUTIÉRREZ, Guillermo. (2003). El Taller Reflexivo. Medellín. Editorial Universidad Pontificia Bolivariana. Tercera Edición. p. 30

29 Ibíd., p. 23.

${ }^{30}$ Ibídem.

31 Miguel Ángel Palta, integrante del grupo periodístico del noticiero 90 Minutos , y Leonardo Quintero, periodista del noticiero Noti 5. 
32. GUTIÉRREZ, Guillermo. (2003). ElTaller Reflexivo. Medellín. Editorial Universidad Pontificia Bolivariana. Tercera Edición. p. 111

${ }^{33}$ Las mujeres frente a la violencia y la discriminación derivadas del conflicto armado en Colombia. (2006). Organización de los Estados Americanos. Comisión Interamericana de Derechos Humanos. Washington, D.C. p. 18.

${ }^{34}$ Las mujeres frente a la violencia y la discriminación derivadas del conflicto armado en Colombia. (2006). Organización de los Estados Americanos. Comisión Interamericana de Derechos Humanos. Washington, D.C. p. 39.

35 IBAÑEZ, Ana María. (2008). El desplazamiento forzado en Colombia: Un camino sin retorno hacia la pobreza. Colección Cede 50 años. Universidad de los Andes. p. 18.

${ }^{36}$ SALAZAR, Boris. (2008). ¿A dónde ir? Un análisis sobre el desplazamiento forzado. Cali. Programa Editorial Universidad del Valle. p. 15.

${ }^{37}$ Ibíd., p. 25

${ }^{38}$ SALAZAR., Op. cit., 15.

${ }^{39}$ Folleto: Sigamos la Ruta de Atención en Salud. (2006). Publicado por la UAO (Unidad de Atención y Orientación al Desplazado) de Buenaventura.

40 . Organización de los Estados Americanos. Comisión Interamericana de Derechos Humanos., Op. cit., p. 15.

41 SALAZAR., Op. cit., p. 11.

42 Organización de los Estados Americanos. Comisión Interamericana de Derechos Humanos., Op. cit., p. 46.

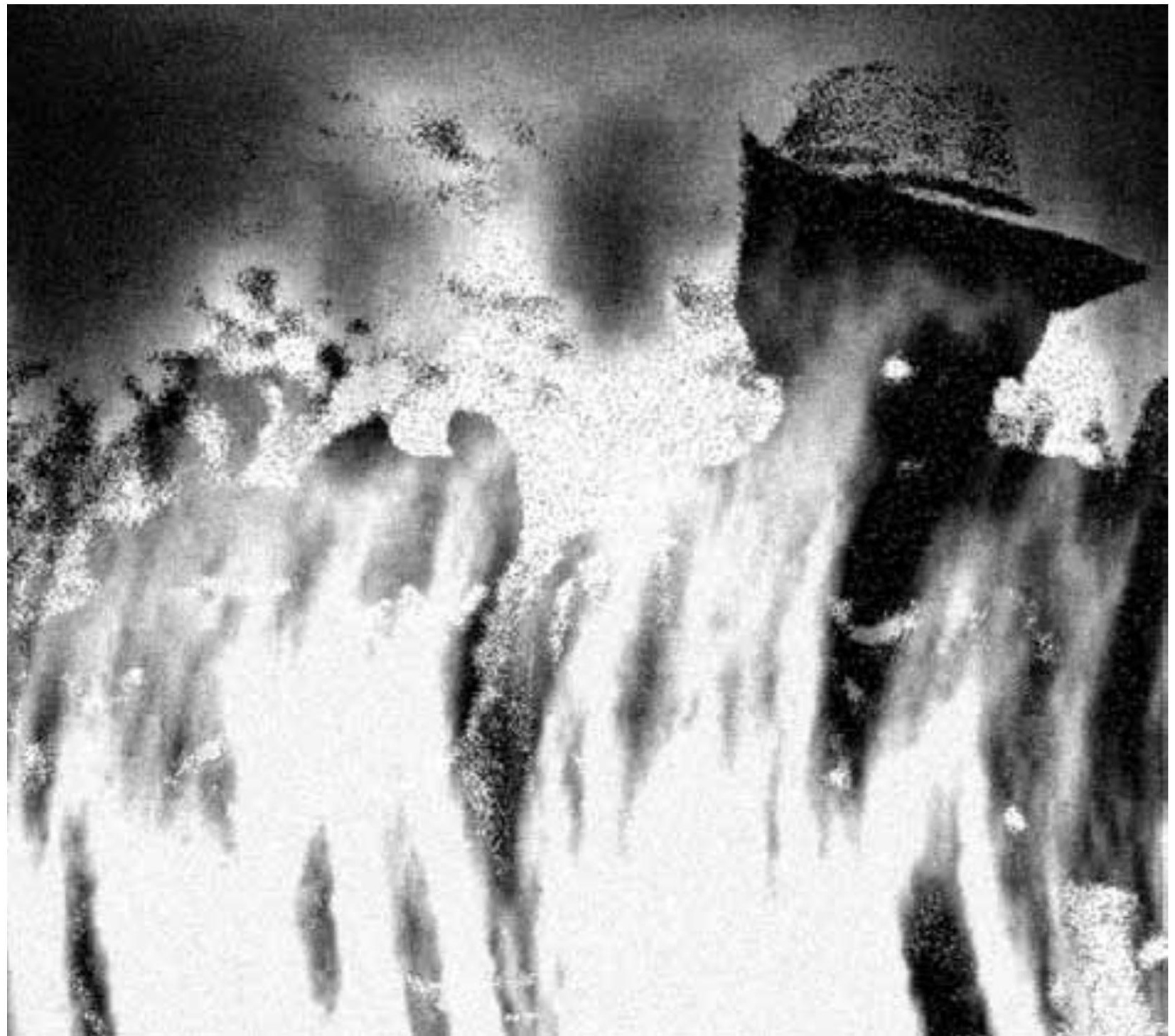




\section{Bibliografía}

ARDILA, Gerardo. (2006, Julio) Cultura y desarrollo territorial”en: conferencia Diplomado Gestión de Procesos Culturales y Construcción de lo Público. Ponencia presentada en el Diplomado Gestión de Procesos Culturales y Construcción de lo Público, Medellín, Colombia.

ARTEAGA, et al. (2005). La Representación de lo indígena en los medios de comunicación. Medellín. Hombre nuevo Editores.

Artículo $1^{\circ}$ Ley 387 de 1997. Diario Oficial. Año CXXXIII No 43091. 24 de julio, 1997. AUGÉ, Marc. (2000). Los no lugares. Espacios del anonimato, una antropología sobre la modernidad. Barcelona 2000. Editorial Gedisa, S.A.

BARNEY, Ernesto. (2008). Cátedra de Desplazamiento Forzado, Tierras y Desplazamiento. ACNUR - Universidad Nacional de Colombia. (CD ROOM)

BOURDIEU, Pierre. (2000). Sobre la Televisión., Barcelona. Editorial Anagrama S.A. Tercera edición.

CARBALLEDA Alfredo J. (2002) "La Intervención en lo social: exclusión e integración en los nuevos escenarios sociales”. Buenos Aires. Editorial Paidós SAICF y Tatanka S.A

CHARAUDEAU, Patrick. (2003). El Discurso de la Información. Barcelona. Editorial Gedisa S.A. CORVALAN R, Javier. (1996) "Los paradigmas de lo social y las concepciones de intervención en la sociedad”. p. 6. Extraído el 23 Septiembre, 2010, de http://www.rau.edu.uy/fcs/dts/Mip1/ corvalan.pdf. No 4 .

Folleto: Sigamos la Ruta de Atención en Salud. (2006). Publicado por la UAO (Unidad de Atención y Orientación al Desplazado) de Buenaventura.

GUBER, Rosana. (2001). La Etnografía, Método, Campo y Reflexividad. Bogotá, 2001. Grupo

Editorial Norma.

GUTIÉRREZ, Guillermo. (2003). ElTaller Reflexivo. Medellín. Editorial Universidad Pontificia

Bolivariana. Tercera Edición.

IBAÑEZ, Ana María. (2008). El desplazamiento forzado en Colombia: Un camino sin retorno hacia la pobreza. Colección Cede 50 años. Universidad de los Andes.

Las mujeres frente a la violencia y la discriminación derivadas del conflicto armado en Colombia.

(2006). Organización de los Estados Americanos. Comisión Interamericana de Derechos Humanos. Washington, D.C.

LONDOÑO, Beatriz, PIZARRO, Rafael (compiladores). (2005). Derechos humanos de la población desplazada, Evaluación de sus mecanismos de protección. Colección de textos de Jurisprudencia. Bogotá

D.C. Centro Editorial Universidad del Rosario.

SARLO, Beatriz. (2007). Tiempo Pasado Cultura de la memoria y giro subjetivo. Una discusión. Argentina S.A. Siglo veintiuno Editores. p. 29.

PARDO, Mauricio (Editor). (2001). Acción Colectiva, Estado y Etnicidad en el Pacífico colombiano. Bogotá, Instituto colombiano de Antropología e historia - Colciencias.

PATIÑO OSSA, Germán. (2007). Fogón de Negros, Cocina y cultura en una región

Latinoamericana. Bogotá. Edición del Convenio Andrés Bello.

Registro de desplazados Expulsión y Recepción, Acción Social, Valle del Cauca.

SALAZAR, Boris. (2008) ¿A dónde ir? Un análisis sobre el desplazamiento forzado. Cali. Programa Editorial Universidad del Valle.

SCHUJMAN, Gustavo, CLÉRICO Laura, CARNOVALE, Vera. (2005). Derechos Humanos y

Ciudadanía. Buenos Aires, Argentina. Aique Grupo Editor S.A.

TORRES, Cristina. (2001). Etnicidad y salud: otra perspectiva para alcanzar la equidad. Washington, D.C. Organización Panamericana de la Salud.

VERÓN, Eliseo. (1983) Construir el acontecimiento. Buenos Aires. Editorial Celtia S.A.C.I.F. de M. y R.

WADE, Peter. (1997). Gente negra; nación mestiza, dinámica de las identidades raciales en Colombia.

Bogotá. Siglo del Hombre Editores, Ediciones Uniandes 1997. p. 319

WADE, Peter. (2000) Raza y Etnicidad en Latinoamérica. Quito. Ediciones Abya - Yala. 